\title{
The production of hydrolysates from industrially defatted rice bran and its surface image changes during extraction
}

Article

Accepted Version

Kaewjumpol, G., Oruna-Concha, M. J., Niranjan, K. and Thawornchinsombut, S. (2018) The production of hydrolysates from industrially defatted rice bran and its surface image changes during extraction. Journal of the Science of Food and Agriculture, 98 (9). pp. 3290-3298. ISSN 0022-5142 doi: https://doi.org/10.1002/jsfa.8832 Available at https://centaur.reading.ac.uk/74513/

It is advisable to refer to the publisher's version if you intend to cite from the work. See Guidance on citing.

To link to this article DOI: http://dx.doi.org/10.1002/jsfa.8832

Publisher: Wiley

All outputs in CentAUR are protected by Intellectual Property Rights law, including copyright law. Copyright and IPR is retained by the creators or other copyright holders. Terms and conditions for use of this material are defined in the End User Agreement. 


\section{CentAUR}

Central Archive at the University of Reading

Reading's research outputs online 
The production of hydrolysates from industrially defatted rice bran and its surface image changes during extraction

Running Title: The production of hydrolysates from industrially defatted rice bran

Geerada Kaewjumpola $^{\mathrm{a}}$, Maria J Oruna-Concha ${ }^{\mathrm{b}}$, Keshavan Niranjan ${ }^{\mathrm{b}}$, and Supawan Thawornchinsombut $\mathrm{a}^{*}$

* Correspondence to: Supawan Thawornchinsombut, Department of Food Technology, Faculty of technology, Khon Kaen University, 40002 Khon Kaen (Thailand), Email: suptha@kku.ac.th

a Department of Food Technology, Faculty of Technology, Khon Kaen University, 40002 Khon Kaen, Thailand

${ }^{b}$ Department of Food and Nutritional Sciences, University of Reading, RG6 6AP Reading, England

\begin{abstract}
BACKGROUND: This research employed mild-subcritical alkaline water extraction (SAW) technique to overcome the difficulty of active compounds extractability from an industrially defatted rice bran (IDRB). Mild-SAW ( $\mathrm{pH} \mathrm{9.5,} 130{ }^{\circ} \mathrm{C}, 120 \mathrm{~min}$ ) treatment, followed by enzymatic hydrolysis (Protease G6) were applied to produce rice bran hydrolysate (RBH). Response surface methodology was used to identify proteolysis conditions for maximizing protein content and ABTS radical scavenging activity (ABTS-RSA). The microstructural changes during the extraction occurring in the IDRB were monitored. The selected RBH was characterised for protein recovery, yield, antioxidant activities, phenolic profile and hydroxymethylfufural (HMF) content.
\end{abstract}

This article has been accepted for publication and undergone full peer review but has not been through the copyediting, typesetting, pagination and proofreading process, which may lead to differences between this version and the Version of Record. Please cite this article as doi: 10.1002/jsfa.8832 
RESULTS: Optimal proteolysis conditions were at $20 \mathrm{~mL} \mathrm{~kg}^{-1}$ IDRB (E/S) for $6 \mathrm{~h}$. Under these conditions, the yield, ABTS-RSA, Ferric reducing antioxidant power and the total phenolic content of the RBH were 46.1\%, $294.22 \mu \mathrm{mol}$ trolox g-1, $57.72 \mu \mathrm{mol} \mathrm{FeSO}_{4} \mathrm{~g}^{-1}$, and $22.73 \mathrm{mg}$ gallic acid $\mathrm{g}^{-1}$, respectively, with relatively low HMF level $\left(0.21 \mathrm{mg} \mathrm{g}^{-1}\right)$. The protein recovery was 4.8 times greater than the recovery obtained by conventional alkaline extraction. Its major phenolic compounds were p-coumaric and ferulic acids. The microstructural changes of IDRB confirmed that the mild-SAW/Protease G6 process enhanced the release of active compounds.

CONCLUSION: The process of mild-SAW followed by proteolysis promotes the release of active compounds from IDRB.

Supporting information may be found in the online version of this article.

Keywords: Rice bran hydrolysate; mild-subcritical alkaline water extraction; phenolic compound; response surface methodology; scanning electron microscope

\section{INTRODUCTION}

Defatted rice bran, containing around $12-20 \%$ protein $^{1}$, is an under-utilized residue of the rice bran oil industry. Due to its high quality and hypoallergenicity, rice bran protein is increasingly used in food product formulation such as those used for infants and people suffering allergies. ${ }^{2}$ It is also possible to produce protein hydrolysates from defatted rice bran, without necessarily isolating the protein in a pure state. Earlier studies have managed to produce protein hydrolysates from heat stabilized ${ }^{3}$ and defatted rice bran ${ }^{4}$. Given the close interactions between phenolics and proteins, it is also possible to produce antioxidant hydrolysate, starting from commercial defatted rice bran. But this has not been attempted so far. The main challenge in producing such products is to be able to achieve high functionality, whilst coping with an inherently poor extractable state of proteins and phenolics in the starting defatted rice bran resulting from the use of organic solvents and 
intense temperatures during oil extraction. $5,6,7$ This is further complicated by the tight physical bonding of various rice bran components to the solid matrix and the complex chemical interactions between the phenolics and proteins, which makes the extraction process itself to be very challenging. For instance, corn germ bran defatted by ethanol or isopropanol at $70{ }^{\circ} \mathrm{C}$ had lower nitrogen solubility index than the raw material. ${ }^{8}$ Vojdani ${ }^{9}$ stated that a decrease in protein solubility is due to protein denaturation by organic solvent as well as the high temperatures employed. Prigent et al. ${ }^{10}$ found that covalent bonds were formed between phenolic compound (chlorogenic acid) and bovine serum albumin at high temperature. In any case, the extraction of proteins and other components are very closely linked, and a background to their extraction is discussed below.

In a typical process, the proteins are solubilized under alkaline conditions and precipitated at the isoelectric point. Carbohydrases ${ }^{3}$ or proteases ${ }^{11}$ are known to increase protein extractability. Protease, in particular, alters the native protein structure to form "protein hydrolysates" or "bioactive peptides" which are known to have a positive influence on human health. ${ }^{12}$ Peptides produced from non-heat-stabilized rice bran are known to exhibit high antioxidant activity. ${ }^{13,14}$ Instead of using enzymes, extraction can also be accomplished under heat and pressure conditions using the so called subcritical water (SW) as the extraction medium. At temperatures around $250^{\circ} \mathrm{C}$, the dielectric constant of SW is comparable to solvents such as ethanol, and can be employed as an effective extraction medium for antioxidative components ${ }^{15}$, as shown in the case of soxhlet defatted rice bran. ${ }^{4,16} \mathrm{~A}$ preliminary study undertaken in our laboratory showed that the protein recovery from IDRB (industrially defatted rice bran by hexane and high temperature) extracted using mild-subcritical alkaline water (mild-SAW) at $\mathrm{pH} 9.5,130{ }^{\circ} \mathrm{C}$ for $2 \mathrm{~h}$ was significantly higher (15.0\%) than those extracted by alkaline extraction ( $\mathrm{pH} 9.5$ and 11.0) (5.1\% and $12.9 \%$, respectively) (Table S1). The combination of mild-SAW and different enzymes were also compared, and the combination of mild-SAW followed by Protease G6 resulted in the highest protein recovery $(21.8 \%)$. However, this protein recovery was still much lower than the values reported in other studies, for instance, in the paper ${ }^{17}$ where SW was mixed with full fat rice bran (50.77-64.21\%) or in the paper ${ }^{18}$ where heat-stabilized rice 
bran was used without employing hexane and high temperature (37.4-50.0\%). It is however important to note that the use of higher temperatures can also lead to toxic hydroxymethylfurfural (HMF) formation in the process $^{19}$, which must be monitored. Therefore, to improve the efficiency of protein extraction, in this current study, optimization of Protease G6 hydrolysis conditions was performed under mild-SAW extraction..

The functionality of the hydrolysate depends strongly on the properties of the starting raw material. In order to elucidate the link between the properties of the starting raw material and the hydrolysate, the microstructures of the raw materials as well as the intermediate chemicals formed after mild-SAW and enzymatic hydrolysis were studied using Scanning Electron Microscopy (SEM). Further, preliminary experiments also revealed that the solvent extraction conditions under which the rice bran was defatted had a strong influence on the rates of protein extraction. It was hypothesised that this difference in rates could be attributed to the different surface topography of the defatted materials which resulted under different extraction conditions. An attempt was therefore made to examine the surface topography using Atomic Force Microscopy (AFM).

The present study aimed to optimize the enzymatic hydrolysis conditions i.e. enzyme concentration $(E / S)$ and hydrolysis time in order to achieve maximum protein content and antioxidant activity of rice bran hydrolysates $(\mathrm{RBH})$ produced from IDRB previously treated by mild-SAW. RBH obtained under the optimal condition was elucidated for yield, protein recovery, antioxidant capacity, and the chemical compositions such as phenolic compounds content and profile, as well as HMF content. The surface topography and microstructural changes during the extraction of the defatted materials were monitored by AFM and SEM, respectively.

\section{MATERIALS AND METHODS}

\section{Materials}

Experiments were conducted with two samples of defatted rice bran: 1. Industrially defatted rice bran (IDRB) obtained by blending full fat rice bran with parboiled rice bran (mixed varieties) in the ratio $1: 1$, heat stabilizing the blend at temperatures between $70-80$ 
${ }^{\circ} \mathrm{C}$ for $30 \mathrm{~min}$ and defatting with hexane at c.a. $70{ }^{\circ} \mathrm{C}$, followed by evaporating the hexane and moisture at $140{ }^{\circ} \mathrm{C}$ (this sample was obtained from Kasisuri Co., Ltd., Ayudhaya, Thailand); and 2. Low temperature defatted rice bran (LDRB) obtained by defatting fresh rice bran (K.C. Rung Ruang Co., Ltd., PLACE, Thailand) with hexane in the ratio of 1:3 (bran:hexane) using a solid-liquid extraction apparatus (UOP4, Armfield, UK) for $3 \mathrm{~h}$ at room temperature, then evaporating the hexane and moisture in fume hood for $24 \mathrm{~h}$. This method is mostly applied in laboratory scale. These two samples represented possible viable starting materials for antioxidant protein hydrolysate extraction.

The other material used in the experimental study was a commercial Protease G6 (PG6) (EC 3.4.21.62) (DuPont ${ }^{\mathrm{TM}}$ Genencor $^{\circledR}$ Science, USA) with activity of 580,000 DU g ${ }^{-1}$, purchased from Siam Victory Chemicals Co., Ltd. (Bangkok, Thailand). The standards for phenolic analysis i.e. vanillic acid, syringic acid, vanillin, p-coumaric acid, ferulic acid and sinapic acid, and 2,4,6-tripyridyl-s-triazine (TPTZ) and ferrozine (3-2-pyridyl)-5,6-diphenyl1-1,2,4-triazine-4'-4"-disulforic acid) were purchased from Sigma (St. Lois, MO, USA). Acetonitrile and methanol (HPLC grade), bovine serum albumin (BSA), 2,2'-azinobis-3ethylzothiazoline-6-sulfonic acid (ABTS), 6-hydroxy-2,5,7,8 tetramethyl-chloroman-2cardoxylic acid (trolox) and 5-(hydroxymethyl)-furfural were purchased from Sigma Aldrich (Steinheim, Germany). Folin-Ciocalteu' phenol reagent was purchased from Carlo Erba Reactifs SA (Val de Ruil, France). All other chemicals were purchased from Ajax Finechem Pty Ltd. (New South Wales, Australia).

\section{Atomic force microscopy (AFM)}

The surface topography of IDRB and LDRB was investigated by spreading a $1 \mathrm{mg} \mathrm{mL}^{-1}$ sample suspension in distilled water on a glass surface, and imaging it using AFM (Nano Wizard III, JPK Instruments, Germany) operated in the non-contact mode. The topographic images were analyzed by Gwyddion 2.47 software.

\section{Preparation of antioxidant rice bran hydrolysate $(\mathrm{RBH})$}


IDRB samples sieved through a 50 mesh screen were dispersed in distilled water (1:7 $(\mathrm{w} / \mathrm{v})$ ratio), and soaked for $18 \mathrm{~h}$. The suspension $\mathrm{pH}$ was adjusted to 9.5 and autoclaved (ES-315, Tomy, Tomy KOGYO Co., Ltd., Japan) at $130{ }^{\circ} \mathrm{C}(1.68 \mathrm{~atm})$ for $2 \mathrm{~h}$, which represented a mild-subcritical alkaline water (mild-SAW) conditions obtained from the preliminary experiment. The rice bran suspension was then added with distilled water to obtain a 1:10 (w/v) ratio before being hydrolysed with PG6 in a fermenter (Biostat $B, B$. Braun Biotech International, Melsungen, Germany). A Central Composite Design (CCD) with two factors: enzyme to substrate ratio (E/S: $20-50 \mathrm{~mL} \mathrm{~kg}^{-1}$ IDRB denoted by $\mathrm{x} 1$ ) and hydrolysis time (2-6 h denoted by $\mathrm{x} 2)$ at five levels, each, were applied as shown in Table 1. Temperature and $\mathrm{pH}$ were kept constant at $60{ }^{\circ} \mathrm{C}$ and 9.5 , respectively. The two dependent $Y$ variables were the resulting protein content and antioxidant activity of the extract. The regression model was

$$
\mathrm{Y}=\beta_{0}+\beta_{1} x_{1}+\beta_{2} x_{2}+\beta_{11} x_{1}^{2}+\beta_{22} x_{2}{ }^{2}+\beta_{12} x_{1} x_{2}
$$

The degree of hydrolysis (\% DH) was also investigated by pH-stat method. ${ }^{20}$ The reaction of enzyme was stopped at $95{ }^{\circ} \mathrm{C}$ for 2 min and centrifuged using a refrigerated centrifuge at $10,000 \times \mathrm{g}$ and $4{ }^{\circ} \mathrm{C}$ for $15 \mathrm{~min}$. The supernatant $(\mathrm{RBH})$ was collected to determine the protein content ${ }^{21}$ and ABTS radical scavenging activity (ABTS-RSA) ${ }^{22}$.

Then the model equation for predicting the optimum response values was verified using the selected conditions. Means of the experimental values were compared with the predicted value and \% error was calculated.

Under optimal condition, RBH solution was freeze dried (Gamma 2-16 LSC plus, Christ, Osterode am Harz, Germany) and kept at $4{ }^{\circ} \mathrm{C}$ wrapped in aluminum foil until analyzed. Yield, protein recovery, antioxidant capacity (ABTS-RSA, $\mathrm{Fe}^{2+}$ chelating activity ${ }^{22}$, and ferric reducing antioxidant power $(\mathrm{FRAP}))^{23}$, the chemical compositions such as phenolic compounds content and profile, as well as HMF content were analyzed. In addition, its protein recovery was compared to that of the conventional extraction from IDRB and LDRB performed at $\mathrm{pH} 11.0$ and 4.5 for protein solubilization and precipitation. ${ }^{24}$ Also, chemical compositions of the starting IDRB and freeze dried RBH powder were also determined. 


\section{Proximate analysis}

The chemical compositions (moisture, crude protein (Kjeldahl analysis with 5.95 conversion factor), crude fat and ash contents) of IDRB and freeze dried RBH powder were analyzed by the Association of Official Analytical Chemists (AOAC) methods. ${ }^{25}$ Yield and protein recovery of freeze dried hydrolysates were calculated as follows:

$$
\begin{aligned}
& \% \text { Yield }=\frac{\text { weight of RBH powder }(\mathrm{g}) \text { obtained }}{100 \mathrm{~g} \text { IDRB used }} \times 100 \\
& \% \text { Protein recovery }=\frac{\text { Protein content in RBH extracted from } 100 \mathrm{~g} \text { IDRB }}{\text { Protein content in } 100 \mathrm{~g} \text { IDRB }} \times 100
\end{aligned}
$$

\section{Analysis of phenolic compounds}

Extraction: One $\mathrm{g}$ of IDRB or freeze dried $\mathrm{RBH}$ was mixed with $10 \mathrm{~mL}$ of methanol $(\mathrm{MeOH})$ :water ratio of $0: 100,100: 0,70: 30$ or $50: 50(\mathrm{v} / \mathrm{v})$ and stirred for $24 \mathrm{~h}$ at room temperature to extract phenolic compounds. All mixtures were centrifuged at $9,084 \times \mathrm{g}$ at 4 ${ }^{\circ} \mathrm{C}$ for $15 \mathrm{~min}$. All supernatants were filtered through $0.45 \mu \mathrm{m}$ and kept at $-20{ }^{\circ} \mathrm{C}$ until analysis. Then, total phenolic content was analyzed and the phenolic composition was identified and quantified.

Total phenolic content (TPC): the determination of TPC was adapted from Iqbal et al. ${ }^{26}$ Supernatant $(200 \mu \mathrm{L})$ of $\mathrm{RBH}$ or IDRB was mixed with $4 \mathrm{~mL}$ of deionized water (DI water), $800 \mu \mathrm{L}$ of Folin reagent (Folin:DI water; $1: 10 \mathrm{v} / \mathrm{v}$ ) and $2 \mathrm{~mL}$ of $0.71 \mathrm{M} \mathrm{Na}_{2} \mathrm{CO}_{3}$. The mixture was vortex and incubated in the dark at ambient temperature for $2 \mathrm{~h}$. Then the absorbance of the resulting blue colour was measured at $765 \mathrm{~nm}$ by UV-Visible spectrophotometer (CE1021, Cecil Instrument Ltd., Cambridge, UK). The calibration curve was established using gallic acid $\left(0-0.3 \mathrm{mg} \mathrm{mL}^{-1}\right)$ as the standard TPC was expressed as mg gallic acid g-1 IDRB or RBH powder.

High-Performance Liquid Chromatography (HPLC) analysis: Supernatant of RBH in $\mathrm{MeOH}$ : water of 0:100, 100:0, 70:30 or 50:50 (v/v) were injected with HPLC system (1200 series, Agilent Technologies, Santa Clara, CA, USA) equipped with DAD detector. Chromatographic conditions were as follows: $30{ }^{\circ} \mathrm{C}$ column temperature, Zorbax SB C18 
column (2.1x100 mm; $1.8 \mu \mathrm{m}$; Agilent Technologies, Santa Clara, CA, USA), $5 \mu \mathrm{L}$ injection volume, $0.2 \mathrm{~mL} \mathrm{~min}^{-1}$ flow rate, and gradient elution program. The mobile phase was (A) formic acid:HPLC water, 0.1:100 (v/v) and (B) formic acid:acetonitrile, 0.1:100 (v/v). Solvent B was increased from 0 to $4 \%$ (0-5 min), followed by $25 \%$ B for 35 min and $50 \%$ B for 15 min, which was kept for an extra 5 min (total run time was 60 min.). Identification was carried out by comparing the retention time to the corresponding standards and external standard method was used to quantify the amount of individual phenolic compounds (0.001-1 $\left.\mathrm{mg} \mathrm{mL}^{-1}\right)$. Detection at $280 \mathrm{~nm}$ was used for quantification of vanillic acid, syringic acid, vanillin, p-coumaric acid, ferulic acid and sinapic acid.

\section{Analysis of hydroxymethylfurfural (HMF)}

The analysis of HMF was adapted from Gökmen and Senyuva. ${ }^{27}$ Freeze dried RBH (1 g) was dissolved in $10 \mathrm{~mL}$ of $\mathrm{DI}$ water and stirred for $30 \mathrm{~min}$ at room temperature. The mixture was filtered through $0.45 \mu \mathrm{m}$ membrane, then the supernatant was injected with the same column as phenolic compound analysis. Chromatographic conditions were as follows: $25{ }^{\circ} \mathrm{C}$ column temperature, $5 \mu \mathrm{L}$ injection volume, $0.2 \mathrm{~mL} \mathrm{~min}^{-1}$ flow rate, and isocratic elution. The mobile phase was $0.01 \mathrm{mM}$ acetic acid in formic acid:water of 0.2:100 $(\mathrm{v} / \mathrm{v})$. Identification was carried out by comparing the retention time to the corresponding standards and external standard method was used to quantify the amount of HMF (0.001-1 $\mathrm{mg} \mathrm{mL}^{-1}$ ) which was detected at $285 \mathrm{~nm}$.

\section{Scanning electron microscopy (SEM)}

The IDRB samples were collected i.e. before and after soaking, after mild-SAW, and after the optimal hydrolysis conditions, then subsequently freeze dried. The microstructure of the freeze dried samples was characterized by Scanning Electron Microscope (SEM S3000 N, Hitachi, Japan) with gold (Au) coating (K 500X sputter coater, Emitech, UK).

\section{Statistical analysis}


All data were expressed as means and standard deviations from two replications. Statistical analysis (except for CCD) was carried out by SPSS version 19 for windows (SPSS Inc., USA) with analysis of variance (ANOVA). Duncan's new multiple range test (DMRT) was conducted to compare means of the individual groups. For CCD, statistical analysis was carried out using the Design Expert software version 5 (Stat-Ease, Inc., Minneapolis, MN, USA). The statistical significance of differences was defined as $P<0.05$.

\section{RESULTS AND DISCUSSION}

\section{Chemical composition}

The chemical composition of IDRB i.e. moisture, protein, fat and ash contents were $8.07 \%, 20.19 \%, 0.83 \%$, and $11.84 \%$, respectively (Table 2 ). Jiamyangyuen et al. ${ }^{24}$ reported such components in LDRB as $12.43 \%, 13.89 \%, 1.92 \%$, and $10.13 \%$, respectively. The harsh conditions used in the rice bran oil industry demonstrated highly efficient extraction process as very low oil but high protein content was retained in IDRB. The high protein content in IDRB indicated a potential protein resource for protein hydrolysate production.

\section{Surface image of defatted rice bran by atomic force microscopy (AFM)}

AFM are useful techniques due to ability to image under more natural conditions and to provide topographic profiles from heights which can be directly measured. Change of surface structure of a raw material and food product affected by processing parameters can be measure by AFM. ${ }^{28}$ Rajan et al. ${ }^{29}$ studied surface characterization by means of AFM of untreated and pyrolysed rice husk at 573-773 K using a muffle furnace. The results showed different surface roughness of the rice husks due to the decomposition of organic matter. In the current study, more surface roughness of the IDRB compared to that of LDRB (hexane extraction at room temperature) was observed from the topographic profiles (Fig. 1a-b). In this case, it might be described that the structure of IDRB was shrinkage by high heat treatment (about $140{ }^{\circ} \mathrm{C}$ ) during solvent removal after hexane extraction. This might also cause protein aggregation and crosslinking with other components leading to lower protein extractability. The protein recovery from IDRB (12.85\%) using alkaline extraction was 
significantly lower than that from LDRB (46.95\%) (Table S2, supporting information). These results are consistent with the observation that limited release of compounds from IDRB occur, due to the more intense extraction conditions prevailing in the industrial scale oil extractor.

\section{Optimization of enzymatic hydrolysis conditions for RBH preparation}

Optimization of PG6 hydrolysis conditions for the production of $\mathrm{RBH}$ with high protein content and antioxidant activity was performed. Protein content $\left(\mathrm{Y}_{1}\right)$ and ABTS-RSA $\left(\mathrm{Y}_{2}\right)$ of $\mathrm{RBH}$ prepared at various conditions (as indicated in Table 1) varied from 13.3 to $28.8 \mathrm{mg}$ $\mathrm{mL}^{-1}$ and 13.9 to $23.8 \mu \mathrm{mol}$ trolox $\mathrm{mL}^{-1}$, respectively (Table 3 ). The degree of hydrolysis was in the range of 18.2-26.6\% (data not shown).

The regression models for these variables $\left(Y_{1}\right.$ and $\left.Y_{2}\right)$ were statistically significant $(P<$ 0.05 ) with $R^{2}=0.8148$ and 0.8700 , respectively indicating that the adjustment of the model to the experimental data was appropriate.

In this case, lacks of fit were not significant $(P>0.05)$. The models were presented in Eq. (4) and (5).

$$
\begin{aligned}
& Y_{1}=7.71+2.94 x_{2} \\
& Y_{2}=12.1+1.64 x_{2}
\end{aligned}
$$

Eq. (4) and (5) indicated that enzyme level or $x_{1}$ had no effect, while hydrolysis time or $x_{2}$ displayed linear effects. These results indicated that protein content and ABTS-RSA increased with the increase of hydrolysis time. The predicted values of $Y_{1}$ and $Y_{2}$ based on the range of $x_{1}$ and $x_{2}$ in RSM were estimated as illustrated in Fig. 2a-b.

Optimal conditions at E/S of $20 \mathrm{~mL} \mathrm{~kg}^{-1}$ IDRB and $6 \mathrm{~h}$ of hydrolysis process with the highest protein content $\left(28.7 \mathrm{mg} \mathrm{mL}^{-1}\right)$ and ABTS-RSA $\left(23.8 \mu \mathrm{mol}\right.$ trolox $\left.\mathrm{mL}^{-1}\right)$ were predicted using the response surface curves (Fig. 2a-b). The highest desirability values (0.796) obtained from two conditions; E/S of $20 \mathrm{~mL} \mathrm{~kg}^{-1}$ IDRB and $6 \mathrm{~h}$ and $\mathrm{E} / \mathrm{S}$ of $50 \mathrm{~mL} \mathrm{~kg}$

${ }^{1}$ IDRB and $6 \mathrm{~h}$ revealed maximal protein content and the highest antioxidant activity. To confirm the validity of the statistical experiment strategies, two additional verification 
experiments at optimal conditions were conducted. Error of the responses was calculated between the observation values and the predicted values. It was found that errors of protein content $\left(\mathrm{Y}_{1}\right)$ and ABTS-RSA $\left(\mathrm{Y}_{2}\right)$ at $\mathrm{E} / \mathrm{S}$ of $20 \mathrm{~mL} \mathrm{~kg}^{-1}$ IDRB and hydrolysis time of $6 \mathrm{~h}$ were $5.56 \%$ and $0.77 \%$, respectively, and those at $\mathrm{E} / \mathrm{S}$ of $50 \mathrm{~mL} \mathrm{~kg}^{-1}$ IDRB) and hydrolysis time of $6 \mathrm{~h}$ were $13.61 \%$ and $5.51 \%$, respectively (Table 4 ). These results demonstrated that the models were adequate for $\mathrm{RBH}$ production using enzymatic hydrolysis pretreated with mildSAW (selected from a preliminary experiment). The conditions at E/S of $20 \mathrm{~mL} \mathrm{~kg}^{-1}$ IDRB and hydrolysis time of $6 \mathrm{~h}$ were chosen as optimal conditions due to lower enzyme used.

\section{Properties of freeze dried rice bran hydrolysates $(\mathrm{RBH})$ powder \\ Protein recovery}

In freeze-dried RBH powder (prepared at the optimal conditions), moisture, protein, fat and ash contents were 4.74, 26.85, 0.07 and 11.19\%, respectively (Table2). Yield and protein recovery (based on the mass of IDRB taken) of RBH powder were $46.06 \%$ and $61.27 \%$, respectively (Table 2 ), which demonstrates that mild-SAW treated IDRB followed by PG6 hydrolysis can increase protein recovery by a factor of 4.8 compared to the conventional alkaline extraction(12.85\%) (Table S2, supporting information).

The protein recovery was in the range of $50.77-64.21 \%$ reported by Rahim et al. ${ }^{17}$ but was higher than the study of Xia et al. ${ }^{18}$. Rahim et al..$^{17}$ extracted proteins from full-fat rice bran by autoclaving at $140{ }^{\circ} \mathrm{C}$ with water for $15-60 \mathrm{~min}$. While, Xia et al. ${ }^{18}$ extracted proteins from heat-stabilized rice bran by hydrothermal treatment at 120 and $150{ }^{\circ} \mathrm{C}$ for 60 sec $(\mathrm{pH} 9.0)$ and obtained protein recovery of 37.4 and $50.0 \%$, respectively. These results showed that SW can be applied to enhance protein and carbohydrate extractions from rice bran. The mild-SAW treatment was assumed to disrupt the IDRB structure before extracting protein by proteolysis as demonstrated in SEM results. The role of PG6 is similar to Alcalase which is endoprotease breaking peptide bonds inside peptide chain. Hanmoungjai et al. ${ }^{30}$ optimized Alcalase conditions (E/S: $0-20 \mathrm{~g} \mathrm{~kg}^{-1}$ bran, hydrolysis time: 1-3 $\mathrm{h}$ and temperature: $40-60^{\circ} \mathrm{C}$ ) by RSM to extract protein from full fat rice bran. The protein recovery at the optimal conditions $\left(1 \mathrm{~g} \mathrm{~kg}^{-1}\right.$ bran at $50{ }^{\circ} \mathrm{C}$ and $\mathrm{pH} 9$ for $2 \mathrm{~h}$ ) was $68 \%$ 
being comparative to our result $(61 \%)$. Hanmoungjai et al. ${ }^{30}$ found a significant effect of enzyme concentration but hydrolysis time while our study revealed the opposite trend. This might be due to the difference of raw material and treatment used; full fat rice bran used by Hanmoungjai et al..$^{30}$ against the IDRB used in this study. Also, IDRB had been pretreated by soaking and mild-SAW treatment.

\section{Phenolic compounds}

There have been reports published which state that the antioxidant compounds and antioxidant activities of the extracts strongly depend on the solvent used for the extraction, due to the different chemical properties, especially the polarity. ${ }^{31}$ Therefore, the selection of a solvent that is suitable for the extraction system is extremely important since the structure and matrix composition of each matrix-solvent system can be diverse. ${ }^{32}$ Several studies have shown that methanol $(\mathrm{MeOH})$ at different concentration is frequently used for phenolic compounds extraction from plants. ${ }^{33,34}$ In this study, phenolic compounds were extracted from IDRB and freeze dried $\mathrm{RBH}$ powder using different $\mathrm{MeOH}$ :water (100:0 or $\mathrm{MeOH}$, 70:30, 50:50, and 0:100 or water $(\mathrm{v} / \mathrm{v}))$. The highest TPC of $3.74 \mathrm{mg}$ gallic acid $\mathrm{g}^{-1}$ was extracted with $70: 30 \mathrm{MeOH}$ :water, which was not significantly different to extraction with 50:50 MeOH:water $(P>0.05)($ Table 5$)$. The study by Butsat and Siriamornpun ${ }^{35}$ reported 2.5-2.7 mg gallic acid $\mathrm{g}^{-1}$ derived from Khao Dawk Mali 105 (full fat) rice bran extracted with 80:30 MeOH:water. The sample using only $\mathrm{MeOH}$ as an extracting medium contained the lowest TPC $(P<0.05)($ Table 5$)$ indicating that most phenolic compounds in rice bran have relative polar property. Similarly, Wanyo et al. ${ }^{36}$ reported that the higher the solvent polarity (acetone $<$ ethanol<water), the greater the TPC contained in the extracts from full fat rice bran (8.96, 10.17 and $11.34 \mathrm{mg}$ gallic acid $\mathrm{g}^{-1}$ dry weight, respectively).

Many phenolic acids are naturally bound to cell wall components and proteins. ${ }^{37}$ With the oil extraction process phenolic acids in the IDRB might strongly link with other components thus being less extractability. Nonetheless, the RBH contained 6.0-7.4 times higher TPC than in its raw material (IDRB) (Table 5) indicating that mild-SAW followed by PG6 hydrolysis was more capable of extracting phenolic compounds than using extracting 
medium alone. Pourali et al. ${ }^{16}$ revealed that extracting medium under SW condition (100$360{ }^{\circ} \mathrm{C}$ for $10 \mathrm{~min}$.) applied to defatted rice bran enhanced the release of TPC from 5 to 42 mg ferulic acid equivalents $\mathrm{g}^{-1}$ dry matter when temperature increased from 150 to $220{ }^{\circ} \mathrm{C}$. Similarly, Wiboonsirikul el al. ${ }^{4}$ extracted phenolic compounds from defatted rice bran by SW at temperature range of $50-200{ }^{\circ} \mathrm{C}$ for $5 \mathrm{~min}$ and found that TPC increased as temperature increased ( 1-30 mg gallic acid $\mathrm{g}^{-1}$ bran), whereas at $130{ }^{\circ} \mathrm{C}$ TPC was lower than $5 \mathrm{mg}$ gallic acid g-1 bran.

Wanyo et $a l^{38}$ found ferulic, protocatechuic, gallic and vanillic acids as the major phenolic acids in Khao Dawk Mali 105 rice bran. In the current study, six phenolic compounds were identified but four main phenolic acids (vanillin, p-coumaric acid, ferulic acid, and sinapic acid) were remarkable in $\mathrm{RBH}$ extracted with different $\mathrm{MeOH}$ :water ratios. The results demonstrated that the $70: 30$ ratio can dissolve more vanillic acid, vanillin, ferulic acid, and syringic acid from RBH better than others, while water was the best solvent to extract p-coumaric acid. The first and the second high amount of phenolic compounds in RBH were p-coumaric and ferulic acids (Table 6). Conversely, Pourali et al. ${ }^{16}$ found protocatechuic acid and vanillic acid as major phenolic compounds in extracts from defatted rice bran (defatted by soxhlet extraction at room temperature) using subcritical treatment $\left(220^{\circ} \mathrm{C}, 15 \& 23 \mathrm{~min}\right.$, respectively). No protocatechuic acid and little vanillic acid content were detected in our RBH sample. They were extractable at different conditions which related to the dielectric constant and polarity of the media affected by subcritical condition. Moreover, in rice bran cell wall, the phenolic compounds are bound with lignin and carbohydrates (hemicelluloses and cellulose) ${ }^{16}$ in which SW could positively hydrolyze rice bran and dissolve phenolic compounds at the appropriate conditions.

\section{Antioxidant activity}

The antioxidant activities of RBH powder such as ABTS-RSA, $\mathrm{Fe}^{2+}$ chelating activity and FRAP were $294.22 \pm 5.47 \mu \mathrm{mol}$ trolox $\mathrm{g}^{-1}, 79.76 \pm 1.36 \mathrm{mg} \mathrm{EDTA}^{-1}$ and $57.72 \pm 0.13$ $\mu \mathrm{mol} \mathrm{FeSO}_{4} \mathrm{~g}^{-1}$, respectively. Our RSM study revealed a correlation between active compound content, the protein released from IDRB and ABTS-RSA of the RBH (Fig. 2a-b). 
The lowest protein content and ABTS-RSA were observed in RBH produced employing the shortest hydrolysis time $(1.17 \mathrm{~h})$, while the highest protein content and ABTS-RSA were observed in the RBH produced under optimal conditions (E/S of $20 \mathrm{~mL} \mathrm{~g}^{-1}$ and $6 \mathrm{~h}$ ).

Different protein contents, phenolic compounds and antioxidant activities were reported in earlier studies, because these studies employed different raw materials and extraction methods. Watthanasiritham et al. ${ }^{39}$ produced freeze dried rice bran protein from defatted rice bran (Khao Dawk Mari 105) (defatted by hexane at room temperature) using alkaline extraction ( $\mathrm{pH} 9.5)$, followed by acid precipitation $(\mathrm{pH} 4.5)$. It contained $53 \%$ protein and a phenolic content of $18.78 \mu \mathrm{g}$ gallic acid $\mathrm{g}^{-1}$ with antioxidant capacity of $41.91 \%$ (determined by DPPH) and $92.6 \mu \mathrm{mol} \mathrm{FeSO}_{4} \mathrm{~g}^{-1}$ protein (determined by FRAP). Their study showed much lower phenolic content compared to the present study, probably because the bound phenolic compounds were not dissociated from the bran during conventional alkaline extraction. Moreover, these studies also revealed that freeze drying did not affect antioxidant activity of the protein extract. María et al. ${ }^{40}$ produced rice bran extracts from untreated rice bran and parboiled rice bran using enzymatic extraction (subtilisin, a serine protease, at $0.2 \mathrm{U} \mathrm{g}^{-1}$ protein, $\mathrm{pH} 8,60^{\circ} \mathrm{C}$ for $\left.40 \mathrm{~min}\right)$. The extract from untreated rice bran had higher phenolic content and antioxidant activity determined by ORAC method than the extract from parboiled rice bran. These results also highlight the impact of heat experienced during parboiling on extractability from the bran.

\section{Hydroxymethylfurfural (HMF)}

5-hydroxy methyl furfural (HMF) is an aldehyde and a furan compound. ${ }^{41}$ It is an intermediate compound formed in the Maillard reaction at $\mathrm{pH} 7$ or below when hexoses are involved. ${ }^{42}$ Generally, HMF is formed as a result of the reaction between reducing carbohydrates and proteins and its formation is induced by high temperature during food processing or storage. ${ }^{43}$ In this study, HMF may be induced by heat and acidic $\mathrm{pH}$ during mild-SAW. The $\mathrm{pH}$ of the mixture before being subjected to mild-SAW was adjusted to $\mathrm{pH}$ 9.5 however $\mathrm{pH}$ of the mixture was decreased to $\sim 6$ due to hydrogen ion broken down from alkaline water under mild-SAW condition. 
The HMF content was $0.208 \pm 0.007 \mathrm{mg} \mathrm{g}^{-1} \mathrm{RBH}$ or equal to $0.096 \pm 0.003 \mathrm{mg} \mathrm{g}^{-1}$ IDRB (calculated based on HMF content in $\mathrm{RBH}$ extracted from $1 \mathrm{~g}$ IDRB). Kataoka et al. ${ }^{44}$ prepared wheat bran hydrolysates by SW at various temperatures $\left(50-250{ }^{\circ} \mathrm{C}\right)$ for $5 \mathrm{~min}$ and found that HMF contents markedly increased at temperature above $200{ }^{\circ} \mathrm{C}$ and the highest HMF content was around $20 \mathrm{mg} \mathrm{g}^{-1}$ bran at $240{ }^{\circ} \mathrm{C}$. Abraham et al. ${ }^{19}$ reviewed papers concerning the experiment of HMF toxic in animal (mice and rat) and reported that in the range of $80-100 \mathrm{mg}$ dose $\mathrm{kg}^{-1}$ body weight per day, no toxic effect was perceived. Thus, the RBH obtained in this study is likely to be safe for consumption considering the low HMF content.

\section{Microstructure of IDRB before and after RBH extraction/hydrolysis}

The microstructure of IDRB before and after RBH extraction using mild-SAW followed by PG6 hydrolysis at the optimal conditions (E/S of $20 \mathrm{~mL} \mathrm{~kg}^{-1}$ IDRB and hydrolysis time of 6 h) was characterized by SEM. From the results, it could be observed that the microstructure of IDRB (passed through solvent extraction and heat) was tightly packed, while IDRB soaked in alkaline water $(\mathrm{pH} 9.5)$ revealed more porosity and swelling structure compared with the IDRB with no treatment (Fig. 3a-b).The IDRB treated with only mildSAW (Fig. 3c) and treated with mild-SAW followed by PG6 hydrolysis (Fig. 3d) had lightly packed structure and larger pore size possibly implying that more components were extractable. These results indicated that using these processes combination may promote the release of bioactive components such as protein and phenolic compounds from IDRB.

\section{CONCLUSIONS}

The surface images from AFM analysis demonstrated structural changes of defatted rice bran due to heat and chemical treatments during oil extraction causing a difficult release of compounds including phenolic compounds and proteins from IDRB. The optimal conditions for RBH extraction, using mild-SAW followed by PG6 in order to attain the highest ABTS$\mathrm{RSA}$, were $\mathrm{E} / \mathrm{S}$ of $20 \mathrm{~mL} \mathrm{~kg}{ }^{-1}$ IDRB and hydrolysis time of $6 \mathrm{~h}$ at $60{ }^{\circ} \mathrm{C}$ and $\mathrm{pH} 9.5$. This process can successfully extract more protein from the IDRB, resulting in 4.8 times greater 
protein recovery than conventional alkaline extraction. Moreover, the combined processes of mild-SAW and protease hydrolysis enhanced phenolic compounds extraction by factors of 6.0-7.4, compared to using solvent extraction alone. Release of bioactive components from IDRB was exerted by the combined mild-SAW and PG6 hydrolysis process as evidenced by changes of IDRB microstructures through the extraction process. The achieved RBH possess antioxidant capacity with low level of HMF. This study demonstrates an efficient extraction method for recovering natural antioxidants from a tightly bound structure of defatted rice bran.

\section{ACKNOWLEDGEMENTS}

This work was funded by the Thailand Research Fund through the Royal Golden Jubilee Program (RGJ Grant No.PHD/0128/2553) with Khon Kaen University and the Agricultural research development agency (Public organization). Special thanks to Mr. Varapong Supachok, Kasisuri Co., Ltd. for supplying raw material (IDRB).

\section{SUPPORTING INFORMATION}

Supporting information may be found in the online version of this article.

\section{REFERENCES}

1 Saunders RM, The properties of rice bran as a food stuff. Cereal Foods World 35:632-662 (1990).

2 Helm RM and Burks AW, Hypoallergenicity of rice bran protein. Cereal Foods World 41:839-843 (1996).

3 Tang S, Hettiarachchy NS, Eswaranandam S and Crandal P, Protein extraction from heat-stabilized defatted rice bran: II. The role of amylases, celluclast, and viscozyme. J Food Sci 68:471-475 (2003).

4 Wiboonsirikul J, Kimura Y, Kadota M, Morita H, Tsuno T and Adachi S, Properties of extracts from defatted rice bran by its subcritical water treatment. J Agric Food Chem 55:8759-8765 (2007). 
5 Arafat $\mathrm{M}$ and Basuny $\mathrm{M}$, Production of low acidity rice bran oil by heating process. Peak J Food Sci Technol 1:13-18 (2013).

6 Gerrard JA, Lasse M, Cottam J, Healy JP, Fayle SE, Rasiah I et al., Aspects of physical and chemical alterations to proteins during food processing some implications for nutrition. J Nutr 108:288-297 (2012).

7 Matouk AM, El-Kholy MM, El-Sadany M and Hendawy YT, Rice bran oil extraction using an expeller machine. Misr J Agric Eng 26:324-342 (2009).

8 Navarro SLB, Capellini MC, Aracava KK and Rodrigues CEC, Corn germ-bran oils extracted with alcoholic solvents: Extraction yield, oil composition and evaluation of protein solubility of defatted meal. FBP 100:185-194 (2016).

9 Vojdani F, Methods test, In Protein Function, ed. By Hall GM. Blackie Academic \& Professional, London, pp. 11-60 (1996)

10 Prigent SVE, Gruppen H, Visser AJWG, Van Koningsveld GA, De Jong GAH and Voragent AGJ, Effects of non-covalent interactions with 5-O-caffeoylquinic acid (chlorogenic acid) on the heat denaturation and solubility of globular proteins. J Agri Food Chem 51:5088-5095 (2003).

11 Hamada JS, Characterization and functional properties of rice bran proteins modified by commercial exoproteases and endoproteases. J Food Sci 65:305-310 (2000).

12 Kitts DD and Weiler KA, Bioactive proteins and peptides from food sources applications of bioprocesses used in isolation and recovery. Curr Pharm Design 9:1309-1323 (2003).

13 Adebiyi AP, Adebiyi AO, Ogawa T and Muramoto K, Purification and characterization of antioxidative peptides from unfractionated rice bran protein hydrolysates. Int J Food Sci Technol 43:35-43 (2008).

14 Chanput W, Theerakulkait C and Nakai S, Antioxidative properties of partially purified barley hordein, rice bran protein fractions and their hydrolysates. J Cereal Sci 49:422-428 (2009). 
15 Sereewatthanawut I, Prapintip S, Watchiraruji K, Goto M, Sasaki M and Shotipruk A, Extraction of protein and amino acids from deoiled rice bran by subcritical water hydrolysis. Bioresour Technol 99:555-561 (2008).

16 Pourali O, Feridoun SA and Yoshida $\mathrm{H}$, Production of phenolic compounds from rice bran biomass under subcritical water conditions. Chem Eng J 160:259-266 (2010).

17 Rahim NIA, Morad NA and Long K, Rice bran water extraction through autoclaving and sonication: protein content and amino acid profile. J Appl Sci Agri 10:97-103 (2015).

18 Xia N, Wang J, Yang X, Yin S, Qi J, Hu L and Zhou X, Preparation and Characterization of Protein from Heat-Stabilized Rice Bran Using Hydrothermal Cooking Combined with Amylase Pretreatment. J Food Eng 110:95-101 (2012).

19 Abraham K, Gürtler R, Berg K, Heinemeyer G, Lampen A and Appel KE, Toxicology and risk assessment of 5-Hydroxymethylfurfural in food. Mol Nutr Food Res 55:667-678 (2011).

20 Adler-Nissen J, In Enzymatic Hydrolysis of Food Protein. Elsevier Applied Science Publishers, London, pp. 122-124 (1986).

21 Lowry OH, Rosebrough NJ, Farr AL and Randall RJ, Protein measurement with the folin phenol reagent. J Biochem 193:265-275 (1951).

22 Yin LJ, Tong YL and Jlang ST, Improvement of the functionality of minced Mackerel by hydrolysis and subsequent lactic acid bacterial fermentation. J Food Sci 70:172-178 (2005).

23 Thaipong K, Boonprakob U, Crosby K, Cisneros-Zevallos L and Byrne DH, Comparison of ABTS, DPPH, FRAP, and ORAC assays for estimating antioxidant activity from guava fruit extracts. J Food Comp Anal 19:669-675 (2006).

24 Jiamyangyuen S, Srijesdarak $\mathrm{V}$ and Harper WJ, Extraction of rice bran protein concentrate and its application in bread. Songkla J Food Sci Technol 27:55-64 (2005).

25 Association of Official Analytical Chemists (AOAC), Official Methods of Analysis, 17th ed. AOAC, Washington, DC (2000). 
26 Iqbal S, Bhanger $\mathrm{Ml}$ and Anwar F, Antioxidant properties and components of bran extracts from selected wheat varieties commercially available in Pakistan. LWT-Food Sci Technol 40:361-367 (2007).

27 Gökmen $V$ and Senyuva $H Z$, Improved method for the determination of hydroxymethylfurfural in baby foods using liquid chromatography-mass spectrometry. J Agri Food Chem 54:2845-2849 (2006).

28 Morris VJ. Atomic force microscopy (AFM) and related tools for the imaging of foods and beverages on the nanosccale. In Nanotechnology In the Food, Beverage and Nutracceutical Industries, ed. By Huang Q. Woodhouse Publishing Ltd., Cambridge, pp. 99-148 (2012).

29 Vempati RK, Musthyala SC, Mollah YA and Cocke DL, Surface analyses of pyrolysed rice husk using scaning force microscope. Fuel 74: 1722-1725 (1995).

30 Hanmoungjai $\mathrm{P}$, Pyle DL and Niranjan K, Enzymatic process for extracting oil and protein from rice bran. J Am Oil Chem Soc 7:817-821 (2001).

31 Moure A, Cruz JM, Franco D, Dominguez JM, Sineiro J, Dominguez H et al., Natural antioxidants from residual sources. Food Chem 72:145-171 (2001).

32 Al-Farsi M and Lee CY, Optimization of phenolics and dietary fibre extraction from date seeds. Food Chem 108:977-985 (2008).

33 Jakobok L, Boc $M$ and Barron AR, Optimization of ultrasonic-assisted extraction of phenolic compounds from apples. Food Anal Methods 8:2612-2625 (2015).

34 Wanna A and Klangpetch W, Effect of concentration on total phenolic content, antioxidant activity and antibacterial activity of spent coffee ground extract. IJASEAT 4:132-135 (2016).

35 Butsat S and Siriamornpun S, Antioxidant capacities and phenolic compounds of the husk, bran and endosperm of Thai rice. Food Chem 119:606-613 (2010).

36 Wanyo P, Kaewseejan N, Meeso N and Siriamornpun S, Bioactive compounds and antioxidant properties of different solvent extracts derived from Thai rice by-products. Appl Biol Chem 59:373-384 (2016). 
37 Hartley RD, Morrison WH, Himmelsbach D S and Borneman NS, Crosslinking of cell wall phenolics to arabinoxylans in graminaceous plants. Phytochem 29:3701-3709 (1990).

38 Wanyo P, Meeso N, Siriamornpun S, Effects of different treatments on the antioxidant properties and phenolic compounds of rice bran and rice husk. Food Chem 157:457-463 (2014).

39 Wattanasiritham L, Kubglomsong S and Therakulkait C, Antioxidant Activity of Rice Bran Protein Extract, its Enzymatic Hydrolysates and its Combination with Commercial Antioxidants. PJN 14:647-652 (2015).

40 María CS, Revilla E, Rodríguez-Morgado B, Castanõ A, Carbonero P, Gordillo B et al., Effect of rice parboiling on the functional properties of an enzymatic extract from rice bran. J Cereal Sci 72:54-59 (2016).

41 Makawi SZA, Taha MI, Zakaria BA, Sidding B, Mahmod H, Elhussein ARM et al., Identification and quantification of 5-hydroxymethyl furfural HMF in some sugarcontaining food products by HPLC. Parkistan J Nutr 8:1391-1396 (2009).

42 Martins SIFS, Jongen WIF and van Boekel MAJS, A review of Maillard reaction in food and implications to kinetic modeling. Trends Food Sci Technol 11:364-373 (2001).

43 Vorlová L, Borkovcová I, Kalábová and Vecerek V, Hydroxymethylfurfural contents in foodstuffs determined by HPLC method. J food and Nutr Res 45:34-38 (2006).

44 Kataoka M, Wiboonsirikul J, Kimura $Y$ and Adachi S, Properties of extracts from wheat bran by subcritical water treatment. Food Sci Technol Res 14:553-556 (2008). 


\section{Figure legends}

Figure 1. AFM topographic profiles of IDRB (a) and LDRB (b).

IDRB: Industrially defatted rice bran; LDRB: Low temperature defatted rice bran.

Figure 2. Response surface plots showing effects of E/S and hydrolysis time on protein content (a) and ABTS radical scavenging activity (b) of RBH extracted from IDRB.

$\mathrm{RBH}$ : rice bran hydrolysate; IDRB: Industrially defatted rice bran.

Figure 3. Surface images by SEM of IDRB without any process (a), soaked in water (b), treated with mild-SAW $\left(130^{\circ} \mathrm{C}, 2 \mathrm{~h}\right.$.) (c), treated with mild-SAW followed by enzymatic hydrolysis (PG6) (E/S of $20 \mathrm{~mL} \mathrm{~kg}^{-1}$ IDRB, hydrolysis time of $6 \mathrm{~h}$ ) (d).

IDRB: Industrially defatted rice bran. 

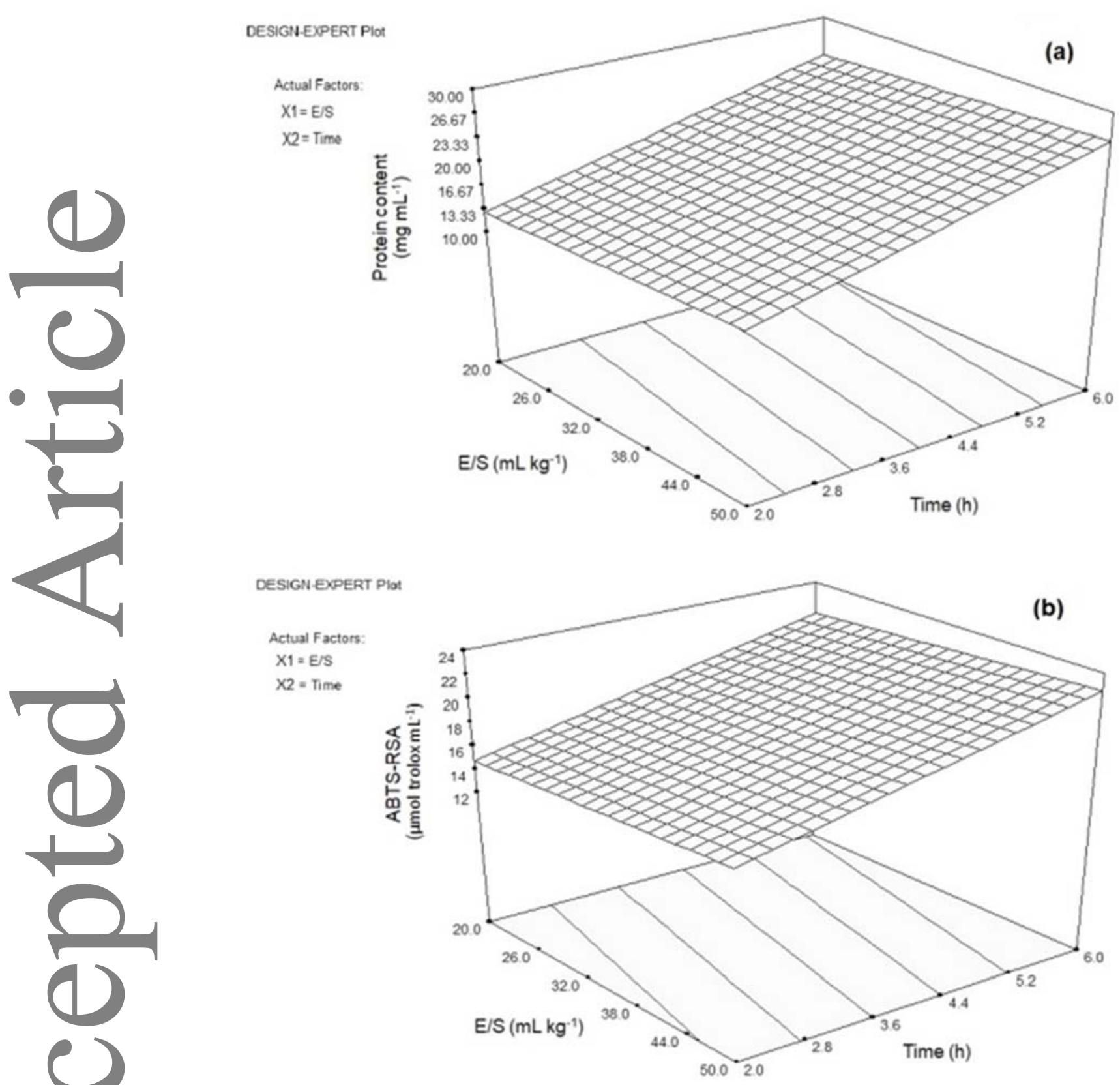

Figure 2. 

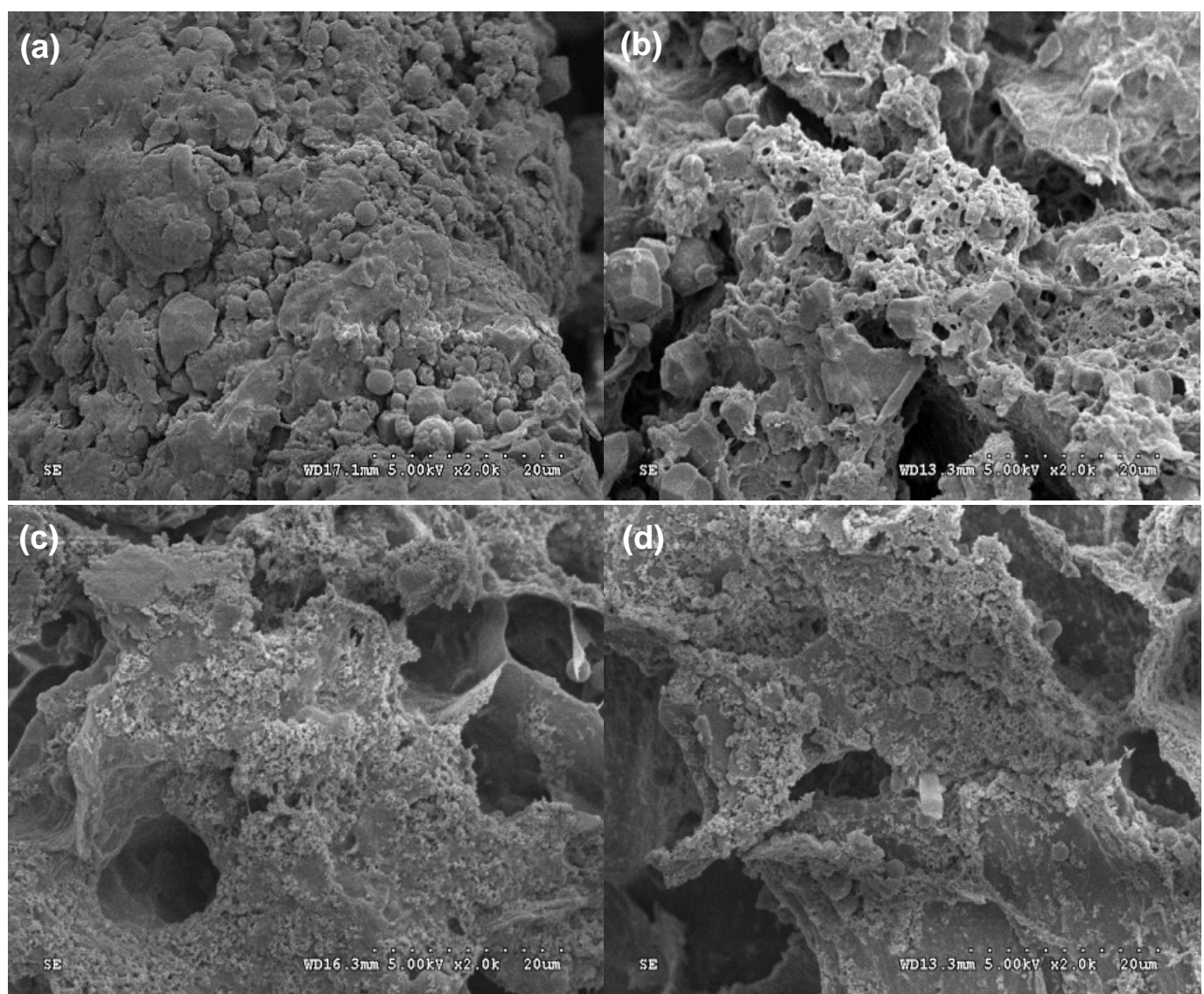

Figure 3. 
Table 1. Factors and levels of the hydrolysis conditions employed for $\mathrm{RBH}$ preparation using Central Composite Design.

\begin{tabular}{cccccc}
\hline & \multicolumn{5}{c}{ Code levels } \\
\hline Factor & $-\alpha$ & -1 & 0 & +1 & $+\alpha$ \\
E/S $\left(\mathrm{mL} \mathrm{kg}^{-1}\right): \mathrm{x}_{1}$ & 1.38 & 2 & 3.50 & 5 & 5.62 \\
Hydrolysis time $(\mathrm{h}): \mathrm{x}_{2}$ & 1.17 & 2 & 4 & 6 & 6.83 \\
\hline
\end{tabular}

$\mathrm{RBH}$ : Rice bran hydrolysate. 
Table 2. Chemical compositions of IDRB and freeze dried RBH powder, and yield and protein recovery of $\mathrm{RBH}$ powder.

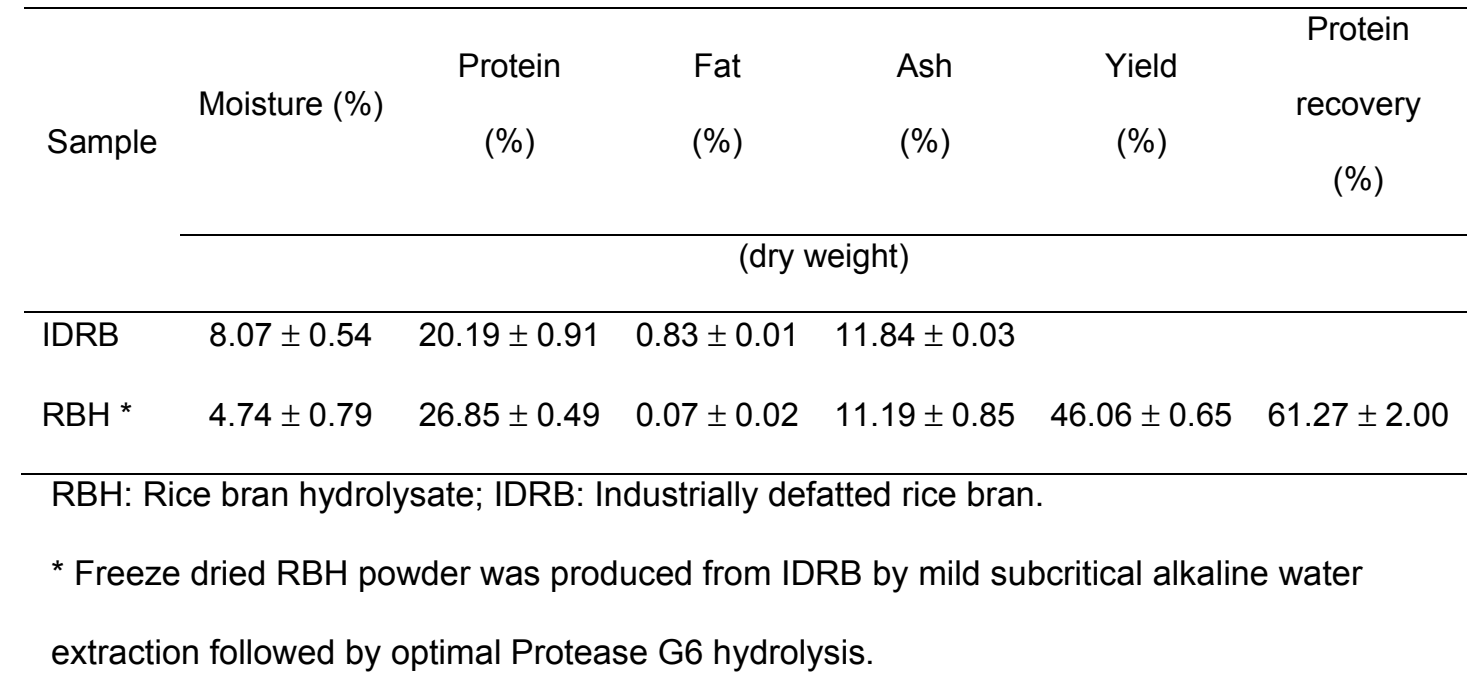


Table 3. Actual levels of independent variables ( $E / S$ and hydrolysis time) along with the tested values of protein content and ABTS radical scavenging activity (ABTS-RSA) of the $\mathrm{RBH}$.

\begin{tabular}{|c|c|c|c|c|}
\hline \multirow[b]{2}{*}{ No. } & \multicolumn{2}{|c|}{ True value } & \multirow{2}{*}{$\begin{array}{l}\text { Protein content } 1,2 \\
\qquad\left(\mathrm{mg} \mathrm{mL}^{-1}\right)\left(\mathrm{Y}_{1}\right)\end{array}$} & \multirow{2}{*}{$\begin{array}{c}\text { ABTS-RSA }{ }^{1} \\
\left(\mu \mathrm{mol} \text { trolox } \mathrm{mL}^{-1}\right)\left(\mathrm{Y}_{2}\right)\end{array}$} \\
\hline & $\begin{array}{c}\text { E/S }\left(\mathrm{mL} \mathrm{kg}^{-1}\right) \\
\left(\mathrm{x}_{1}\right)\end{array}$ & $\begin{array}{l}\text { Hydrolysis time }(\mathrm{h}) \\
\qquad\left(\mathrm{x}_{2}\right)\end{array}$ & & \\
\hline 1 & 20.0 & 2 & $14.66 \pm 0.06^{b}$ & $15.60 \pm 0.09^{b}$ \\
\hline 2 & 50.0 & 2 & $15.72 \pm 0.08^{\mathrm{cd}}$ & $16.94 \pm 0.03^{d}$ \\
\hline 3 & 20.0 & 6 & $28.72 \pm 0.20^{h}$ & $23.77 \pm 0.30^{j}$ \\
\hline 4 & 50.0 & 6 & $28.80 \pm 0.52^{h}$ & $23.16 \pm 0.06^{i}$ \\
\hline 5 & 13.8 & 4 & $15.21 \pm 0.34^{b c}$ & $16.62 \pm 0.26^{c}$ \\
\hline 6 & 56.2 & 4 & $18.87 \pm 0.08^{g}$ & $19.86 \pm 0.15^{g}$ \\
\hline 7 & 35.0 & 1.17 & $13.30 \pm 0.28^{a}$ & $13.88 \pm 0.03^{a}$ \\
\hline 8 & 35.0 & 6.83 & $27.40 \pm 0.05^{h}$ & $22.14 \pm 0.24^{h}$ \\
\hline 9 & 35.0 & 4 & $18.01 \pm 0.54^{f}$ & $18.15 \pm 0.05^{f}$ \\
\hline 10 & 35.0 & 4 & $17.20 \pm 0.22^{\mathrm{e}}$ & $17.46 \pm 0.02^{\mathrm{e}}$ \\
\hline 11 & 35.0 & 4 & $16.36 \pm 0.12^{d}$ & $17.61 \pm 0.03^{e}$ \\
\hline
\end{tabular}

RBH: Rice bran hydrolysate.

${ }^{1}$ Values in the same column with different letters indicate significant differences $(P<0.05)$.

${ }^{2}$ Protein content was determined by Lowry method. ${ }^{21}$ 
Table 4. Verification experiments of RBH extraction process from IDRB.

\begin{tabular}{lcccc}
\hline \multirow{2}{*}{ Experiment } & \multicolumn{2}{c}{ Condition $^{1}$} & \multicolumn{2}{c}{ Response $^{2}$} \\
\cline { 2 - 5 } & $\mathrm{x}_{1}\left(\mathrm{~mL} \mathrm{~kg}^{-1}\right)$ & $\mathrm{x}_{2}(\mathrm{~h})$ & $\mathrm{Y}_{1}\left(\mathrm{mg} \mathrm{mL}^{-1}\right)$ & $\mathrm{Y}_{2}\left(\mu \mathrm{mol}\right.$ trolox $\left.\mathrm{mL}^{-1}\right)$ \\
\hline $1^{*}$ & 2 & 6 & 26.76 & 21.78 \\
$1^{* *}$ & 2 & 6 & 25.35 & 21.95 \\
$\%$ Error & & & 5.56 & 0.77 \\
$2^{*}$ & 5 & 6 & 28.80 & 23.16 \\
$2^{* *}$ & 5 & 6 & 25.35 & 21.95 \\
$\%$ Error & & & 13.61 & 5.51 \\
\hline
\end{tabular}

RBH: Rice bran hydrolysate; IDRB: Industrially defatted rice bran.

${ }^{1} \mathrm{x}_{1}: \mathrm{E} / \mathrm{S}\left(\mathrm{mL} \mathrm{kg}^{-1}\right), \mathrm{x}_{2}:$ hydrolysis time $(\mathrm{h})$

${ }^{2} \mathrm{Y}_{1}$ : Protein content $\left(\mathrm{mg} \mathrm{mL}^{-1}\right), \mathrm{Y}_{2}$ : ABTS radical scavenging activity $\left(\mu \mathrm{mol}\right.$ trolox $\left.\mathrm{mL}^{-1}\right)$

* Observed values, ${ }^{* *}$ Predicted values of $Y_{1}$ and $Y_{2}$ were calculated from Eq. (4) and (5), respectively. 
Table 5. Total phenolic content (TPC) in IDRB and freeze dried RBH.

\begin{tabular}{|c|c|c|}
\hline \multirow{2}{*}{$\begin{array}{c}\text { Solvent } \\
(\mathrm{MeOH}: \text { water })\end{array}$} & \multicolumn{2}{|c|}{ TPC } \\
\hline & $\begin{array}{c}\text { IDRB }^{*} \\
\left(\mathrm{mg} \mathrm{gallic} \mathrm{acid}^{-1}\right)\end{array}$ & $\begin{array}{c}\mathrm{RBH}^{*} \\
\left(\mathrm{mg} \text { gallic acid } \mathrm{g}^{-1}\right)\end{array}$ \\
\hline $100: 0$ & $1.66 \pm 0.12^{\mathrm{a}}$ & $11.32 \pm 0.01^{c}$ \\
\hline $70: 30$ & $3.74 \pm 0.15^{b}$ & $22.47 \pm 0.20^{d}$ \\
\hline $50: 50$ & $3.37 \pm 0.02^{b}$ & $22.85 \pm 0.15^{d}$ \\
\hline $0: 100$ & $3.09 \pm 0.15^{b}$ & $22.73 \pm 0.19^{d}$ \\
\hline
\end{tabular}

RBH: Rice bran hydrolysate; IDRB: Industrially defatted rice bran.

${ }^{*}$ Mean $\pm S D$; the averages were calculated from 2 replications.

${ }^{\text {a-d }}$ Different letters indicate significant difference among 8 treatments (4 solvents $\times 2$ samples $)(P<0.05)$. 
Table 6. Phenolic compounds in freeze dried $\mathrm{RBH}$ extracted with different ratios of $\mathrm{MeOH}$ :water.

\begin{tabular}{ccccccc}
\hline $\begin{array}{c}\text { Solvent } \\
(\text { MeOH:water })\end{array}$ & $\begin{array}{c}\text { Vanillic } \\
\text { acid }\end{array}$ & $\begin{array}{c}\text { Syringic } \\
\text { acid }\end{array}$ & Vanillin & $\begin{array}{c}\text { p-Coumaric } \\
\text { acid }\end{array}$ & $\begin{array}{c}\text { Ferulic } \\
\text { acid }\end{array}$ & $\begin{array}{c}\text { Sinapic } \\
\text { acid }\end{array}$ \\
\cline { 2 - 7 } & \multicolumn{7}{c}{$\mu \mathrm{g} \mathrm{g}^{-1 *}$} \\
& $0.49 \pm$ & $0.47 \pm$ & $307.03 \pm$ & $2267.23 \pm$ & $991.84 \pm$ & $449.89 \pm$ \\
$70: 30$ & $0.03^{\mathrm{a}}$ & $0.02^{\mathrm{a}}$ & $14.49^{\mathrm{a}}$ & $1.34^{\mathrm{a}}$ & $23.70^{\mathrm{a}}$ & $8.00^{\mathrm{a}}$ \\
& $34.35 \pm$ & $11.53 \pm$ & $620.33 \pm$ & $2669.07 \pm$ & $1101.52 \pm$ & $502.01 \pm$ \\
$50: 50$ & $1.40^{\mathrm{d}}$ & $1.61^{\mathrm{c}}$ & $30.24^{\mathrm{d}}$ & $68.45^{\mathrm{b}}$ & $23.51^{\mathrm{b}}$ & $20.12^{\mathrm{a}}$ \\
& $25.12 \pm$ & $11.23 \pm$ & $505.70 \pm$ & $2627.71 \pm$ & $1091.96 \pm$ & $475.22 \pm$ \\
$0: 100$ & $0.25^{\mathrm{c}}$ & $1.74^{\mathrm{c}}$ & $36.66^{\mathrm{c}}$ & $156.17^{\mathrm{b}}$ & $48.71^{\mathrm{b}}$ & $4.58^{\mathrm{a}}$ \\
& $13.22 \pm$ & $2.87 \pm$ & $433.68 \pm$ & $3006.12 \pm$ & $1055.67 \pm$ & $444.19 \pm$ \\
& $0.77^{\mathrm{b}}$ & $0.37^{\mathrm{b}}$ & $31.15^{\mathrm{b}}$ & $20.39^{\mathrm{c}}$ & $67.84^{\mathrm{ab}}$ & $82.67^{\mathrm{a}}$ \\
\hline
\end{tabular}

RBH: Rice bran hydrolysate.

${ }^{*}$ Mean $\pm S D$; the averages were calculated from 2 replications.

a-d Different letters following the column show significant difference among solvent types $(P$

$<0.05)$. 